\title{
OSMANLI HANEDAN ŞAIRLERI: OSMAN BEY'DEN SULTAN VAHDETTIN'E
}

\author{
Ottoman Dynastic Poets: From Osman Bey to Sultan Vahdettin
}

\section{idris SÖYLEMEZ*}

\section{öz}

İslam medeniyeti sahasına dâhil olan Türkler, kendisinden önce Müslüman olan Arap ve Farslardan dinî, ilmî, kültürel ve edebî sahada fazlasıyla etkilenmişlerdir. Kendisinden önceki İslam medeniyeti sahasında kurulmuş olan Müslüman devletlerin mirasçısı konumunda inşa edilen Osmanlı Imparatorluğu bu kadim gelenekte inşa edilen edebî geleneği benimsemiş ve onu daha üst bir mecraya taşımıştır. Halkın büyük bir kısmının Türkçe konuştuğu bu devlette, ilim dili Arapça ve edebiyat dili Farsçaydı. 13. yüzyıldan itibaren ilkin tercüme daha sonra uyarlama yoluyla dâhil olunmuş olan bu edebî sahada çok kısa bir zaman diliminde güçlü şairler yetiştirilerek onların gayretiyle orijinal eserler ortaya konmuştur. Hayatlarının ilk dönemlerinden itibaren dinî, ilmî ve edebî bakımdan en güzel şekilde yetiştirilen Osmanlı Devleti şehzadeleri edebiyatla ve şiirle çok erken zamanda tanışmışlardır. Osmanlı tahtına geçmiş otuz altı sultan ile bu sultanların şehzadelerinin neredeyse tamamı şiirle alakadar olmuşlardır. Sultanlardan ve şehzadelerden bazıları ise divan, divançe ve farklı meseleleri konu edinen eserler ortaya koyabilecek kadar sanata ve dolayısıyla şiir diline ve nazım şekillerine hâkimdirler. Bu çalışmada "Osmanlı Hanedan Şairleri: Osman Bey'den Sultan Vahdettin'e" isimli eser üzerine bir analiz gerçekleştirilmiştir. Eserin ön sözünden başlayarak eser hakkında bilgiler verilmiş ve eser bütün boyutlariyla tanıtılmıştır.

Anahtar Sözcükler: sultan, şehzade, şair, şiir, meclis.

\section{ABSTRACT}

The Turks, who are included in the field of Islamic civilization, were greatly influenced by the Arabs and the Persians who became Muslim before them. The Ottoman Empire, which was built as the heir of the Muslim states established in the field of Islamic civilization before it, adopted the literary tradition built in this ancient tradition and carried it to a higher medium. In this state, where most of the native people spoke Turkish, the language of science was Arabic and the language of literature was Persian. Starting from the $13^{\text {th }}$ century onwards, in this literary field, which

\footnotetext{
* Dr. Öğr. Üyesi. Nevşehir Hacı Bektaş Veli Üniversitesi, illahiyat Fakültesi, İslam Tarihi ve Sanatları Bölümü, Nevşehir/Türkiye. E-posta: idrisssoylemez@gmail.com. ORCID: 0000-0001-97984453.
}

turnitin

This article was checked by Turnitin. 
was first included through translation and later adaptation, strong poets were trained and original works were produced with their efforts in a very short time. From the first period of their lives, the princes of the Ottoman Empire, who were raised in the best way in terms of religion, science and literature met literature and poetry very early. Thirty-six sultans, who came to the Ottoman throne and almost all of the princes of these sultans were interested in poetry. Some of the sultans and princes, on the other hand, had enough knowledge of the art, the language of poetry and verse forms to produce works on divan, divanche and different issues. In this study, an analysis was carried out on the work named "Osmanlı Hanedan Şairleri: Osman Bey'den Sultan Vahdettin'e [Ottoman Dynastic Poets, From Osman Bey to Sultan Vahdettin]". Starting from the preface of the work, information about the work was provided and the work was introduced in all its dimensions.

Keywords: sultan, prince, poet, poetry, majlis.

Öztoprak, Nihat vd. (2020). Osmanlı Hanedan Şairleri, Osman Bey'den Sultan Vahdettin'e. İstanbul: İdeal Kültür Yayıncılık, 416 sayfa.

Osmanlı İmparatorluğu kadim bir geleneğin devamı olarak İslam medeniyeti sahasında kurulmuş son büyük İslam devletidir. Hz. Peygamberle başlayan dönemin kültürel, siyasi ve sosyal temsilcisi konumunda bulunan devlet yöneticileri yani padişahlar, İslam siyasi anlayışının temsilcileri, kadim Türk devlet geleneğinin mümessilleri olarak altı yüz yıl süren bir değerin inşacısı ve sürdürücüsü olarak karşımıza çıkmışlardır. Hayatın her alanında egemen olan bilginin gerekleriyle donanmış olan padişah ve şehzadeler hayatın her yerinde bu bilginin değerine uygun bir yaşam biçimine sahip olmuşlardır. Yetiştikleri ortam, yetişme biçimleri onları daima ilerde yüklenecekleri o kutsal göreve hazırlama yönündedir. Bu durumda hayatın gerçekleriyle yüzleşecek durumda ve konumda olan şehzadeler daha ilk dönemlerde en iyi şekilde eğitilmiş bilgi ve birikim sahibi olarak bulundukları yerlerde hayatın sıkletini çekecek donanıma sahip olarak yetiştirilmiş ve bunun gereklerini fazlasıyla yerine getirmişlerdir. 1071 Malazgirt zaferiyle birlikte Müslüman Türklerin akın akın geldikleri Anadolu, kısa zaman diliminde farklı bölge ve yerlerde kurulmuş olan irili ufaklı yönetim organizasyonlarıyla bir Müslüman yurdu olmuştur. Doğusundan en batısındaki uca Anadolu Selçuklu Devleti'nin himayesinde kurulmuş ve varlığını sürdürmüş beyliklerden biri de, beyleri Ertuğrul Bey ile birlikte gelip yerleştikleri Anadolu'da kısa zaman diliminde yıldızı parlayıp devlet olma yönünde adım atan Osmanoğulları ya da Osmanlı Beyliği'dir. Kuruluş olan 1299'dan itibaren tarih sahnesinden çekilip yerini mirasçısı genç Türkiye Cumhuriyeti'ne bırakmasına kadarki süreçte otuz altı sultan hüküm sürmüştür. Bursa'nın Or- 
han Bey tarafından fethedilmesi ile birlikte devlet, Fatih Sultan Mehmet ile 1453 tarihinde bütün kurum ve kuruluşlarıyla bir cihan devleti ya da imparatorluğu olmuştur. Kadim bir geleneğin mirasçısı konumunda bulunan devletin başındaki padişahlar şehzadelikleri döneminden itibaren iyi bir eğitim görmüştür. Siyasi, ekonomik ve sosyal bilgi dağarcığının yanı sıra edebî, dinî ve fenni bilgilerle donatılmışlardır. Yönetici olmanın gereği olarak sahip oldukları bu bilgi birikimi onların çevresinde ilmî ve edebi meclislerin kurulmuş olmasına da olanak sağlamıştır. Yönetici, âlim ve şair kimlikleriyle temayüz eden bu yöneticiler, şiiri bilen, tanıyan ve ondan zevk alacak bir şekilde yetiştirildikleri gibi her biri şiir yazabilecek hatta önemli eserler ortaya koyabilecek bir donanıma sahiptirler.

Türk edebiyatı sahasında geçmişten günümüze Osmanlı İmparatorluğu'nu yöneten padişahların ve onların şehzadelerinin şairliğini ele alan kimi eserler ortaya konmuştur. "Mustafa isen ve Ali Fuat Bilkan tarafından 1997'de yazılan Sultan Şairler, Hilmi Yücebaş tarafından 1960'ta yazılan Şair Padişahlar, Çoşkun Ak tarafından 2001'de yazılan Şair Padişahlar, Sadettin Kaplan tarafından 2005'te yazılan Sultanların Şiirleri Şiirin Sultanları, İskender Pala tarafından 2010'da yazılmış olan Şiirin Sultanları gibi eserlerin yanı sıra Muhibbi, Selimi ve Avni gibi divanı bulunan padişahlar, Harimi gibi divanı bulunan şehzadeler ve Selim gibi divançesi bulunan padişahlar ayrıca müstakil çalışmaların konusu olmuşlardır.

Fatih Sultan Mehmet Vakıf Üniversitesi Edebiyat Fakültesi Eski Türk Edebiyatı bölümünde öğretim üyesi olarak görev yapan Prof. Dr. Nihat Öztoprak editörlüğünde hazırlanan Osmanlı Hanedan Şairleri külliyatının ilk kitabı olan Osman Bey'den Vahdettin'e adlı bu çalışma divan edebiyatı ya da klasik Türk edebiyatı sahasında yapılacak çalışmalara kılavuzluk ederek önemli bir boşluğu doldurmuştur. 2021 yılında Nihat Öztoprak editörlüğünde ve farklı kalemlerin katkılarıyla hazırlanıp İdeal Kültür Yayıncılık tarafından basılan bu eser, 416 sayfadan meydana gelmektedir. Eserin mizanpajı DBY Ajans tarafından yapılmıştır. Kitap, adından da anlaşılacağı üzere Osman Bey'den Vahdettin'e divanı veya divançesi bulunmayan padişah veya şehzadelerden yirmi dokuz kişinin hayatı ve şiirlerinden örnekler sunmaktadır. Temelde iki bölümden meydana gelen eserin birinci bölümü Osmanlı hanedan şairleri üzerine genel bir değerlendirmeyi, ikinci bölüm ise Osman Bey'den Sultan Vahdettin'e bugün için elde bir takım şiirleri bulunan sultan veya şehzade şairlerin hayatı ve şiirlerini ihtiva etmektedir.

Osman Bey'den Vahdettin'e eseri yukarıda ifade edildiği üzere temelde iki bölümden oluşmakla beraber klasik anlamda bir kitabın sahip olduğu 
temel kompozisyonun tamamını ihtiva etmektedir. Yazarlar, içindekiler, sunuş, ön söz, giriş mahiyetinde birinci bölüm ve akabinde yirmi dokuz padişah veya şehzadenin hayatları hakkında muhtasar bilgilerden sonra şiirlerinden örnekler sunmuşlardır. Eserin birinci bölümü yani "Osmanlı Hanedan Şairleri Üzerine Genel Bir Değerlendirme" kısmı, Osmanlı padişahlarının ve şehzadelerinin ortak yanı olan sanatkârlıkları hakkında muhtasar bilgiler intiva eder. Bu ortak yanın tespiti ve ilim dünyası ile paylaşılması maksadıyla on kitaplık koca bir külliyatın ortaya konulduğunu ifade eden kitabın editörü Nihat Öztoprak, birinci kitabın bu ilk bölümünde yer alan bilgilerin, külliyatın tamamıyla alakalı olduğunu ifade etmektedir. Daha şehzadelik döneminde başlayan etkili bir eğitim döneminin neticesinde Osmanlı sarayının en gözde bireyleri konumunda bulunan saltanat ocağı ve onların müdavimleri yani şehzadeler almış oldukları güçlü ve etkili eğitimin gereğini hayatın her dönemi ve yerinde gösterdikleri gibi sanat mecrasında özellikle şiirde de göstermişlerdir. Hayata tutunmak ve toplumu derinden etkilemek maksadıyla Yavuz Sultan Selim örneğinde olduğu üzere şiirin güçlü yanından fazlasıyla faydalanmışlardır. Kadim geleneğin inşacısı konumundaki ilk Müslüman Türk devletlerinde var olan sultanın etrafında kurulan ve günün şiirlerinin okunduğu ve değerlendirildiği şiir meclisi ve şiirlerini aynı zamanda şair olan ya da şiirden anlayan sultana okuyan şair arasında düzeneği kurulu bulunan geleneğe fazlasıyla bağlı kalan Osmanlı sultanları ve şehzadelerinin saray ve köşkleri şiir ve şair için paha biçilmez birer mekân olagelmiştir. Bu ilişki, padişahı ulema ve şuara meclislerinde sözün tartıcısı veya kıymet biçeni kıldığı gibi halk nazarında da daha kıymetli bir konuma yükseltmiştir. Bu bölüm şu başlıklardan meydana gelmektedir: "Sultanlar Niçin Şiir Yazar ve Onların Şiirleri Neden Önemlidir", "Divanı ve Divançesi Olan Sultanlar", "Az Sayıda Şiiri Olan Sultanlar", "Şiiri Tespit Edilemeyen Sultanlar", "Şiir Yazdığı Bilinen Şehzadeler”, "Hanedandan Kadın Şairler”, "Osmanlı Hanedan Şairlerinin Arapça, Farsça Bilgileri ve Şiirleri", "Farklı Eser Yazan Hanedan Mensupları", "Osmanlı Hanedan Şairlerinde Mahlas", "Hanedan Şairlerinin Şiirde Şekil ve Tür Tercihleri”, "Türkçe Yapı”, "Şiir Karışıklıkları".

Eserin ikinci bölümü olan esas bölümde, eserin yazarları konu dağılımı çerçevesinde ilk dönemden son döneme ya da Osman Bey'den Sultan Vahdettin'e kadar olan kısmı iki başlık halinde kaleme almışlardır. ilk kısımda sultan veya şehzade şairin hayatı ve şiiri hakkında var olan malzemeden ve kaynaklardan hareketle gerekli bilgilere yer veren yazarlar, daha sonra şairlerin şiirlerinden örnekler ve örneklerin günümüz Türkçesi ile karşııklarını 
vererek halktan kopuk olduğu iddiasıyla son yüzyılda çeşitli ilim ve edebiyat meclislerinde tartışılan divan şiirinin halkın tamamına ait ögeleri içinde barındırdığı, devletin yönetim kademesinin en başında yer alan sultandan onun tebaası konumundaki halka kadar herkese hitap eden bir tarafının olduğunu göstermişlerdir.

Osmanlı haneden şairleri üzerine genel bir değerlendirmeyi içeren ilk bölüm ile Osman Bey, Orhan Bey, Sultan I. Murat maddeleri Nihat Öztoprak tarafından kaleme alınmıştır. Harîmî (Şehzade Korkut), Adlî (Sultan II. Mahmut) Sebahat Deniz; Selimî (Sultan II. Selim), Adlî (Sultan III. Mehmet), Ersen Ersoy; Sultan II. Ahmet, ikbâlî-Meftûnî (Sultan II. Mustafa), Necîb (Sultan III. Ahmet) Ozan Yılmaz; Yıldırım (Sultan I. Bayezid), Şehzade Emir Süleyman, Mehemmed (Sultan I. Mehmet), Murâdî (Sultan II. Murat) Bünyamin Ayçiçeği; Şehzade Mustafa, Murâdî (Sultan IV. Murat), Sultan ibrahim, Vefâî (Sultan IV. Mehmet), Hacı ibrahim Demirkazık tarafından kaleme alınmıştır. Selîmî (Yavuz Sultan Selim), Muhlisî (Şehzade Mustafa), Mehemmed (Şehzade Mehmet), Zarifî (Şehzade Cihangir) Hasan Kaya; Sebkatî (Sultan I. Mahmut), Cihângir (Sultan III. Mustafa), Âdile (Âdile Sultan) Ümran Ay Say; Şehzade Mehmet, Sultan I. Abdülhamit, Sultan Abdülaziz, Reşâd (Sultan V. Mehmet) ise Nusret Gedik tarafından kaleme alınmıştır.

Kitabın üçüncü bölümü olarak kabul ettiğimiz "Motifler ve Terimler Sözlüğü” bölümünde kitapta örnekleri sunulan şiirlerden hareketle meselenin daha rahat bir şekilde anlaşıımasını sağlamak maksadıyla elli bir madde muhtasar olarak ele alınıp açıklanmıştır. Kitabın en sonunda ise "Ortak Bibliyografya" isimli kısım yer almaktadır.

Nihat Öztoprak ve alanın uzmanı diğer akademisyenler altı yüz yıllık bir geleneğin başlangıcından son anına kadar tarihî katkıları, değer ve yarattıkları etkiyle eserlere kazınmış sultan ya da adayları konumunda bulunan şehzadeleri bir bütün olarak ele almışlardır. Onların sanatkârlık yönlerini bütüncül bir kompozisyon değeri çerçevesinde gözler önüne serip kimi yönleriyle tozlu raflarda kalan bu kıymetli şahsiyetleri ve yazdıkları eserleri, bu bağlamda insana ve çağa dair söylediklerini bir bütün olarak ortaya koymuş, ilim âlemini ve okurları bu konuda aydınlatmışlardır. Söz konusu eser bu yönüyle de takdiri ve saygıyı fazlasıyla hak etmektedir.

Sonuç olarak şunları söylemek mümkündür: Nihat Öztoprak ve diğer akademisyenler, kaleme aldıkları bu eserle tarihin her safhasında değerli izleri olan büyük sultanlar ve onların göz bebekleri şehzadeler hakkındaki bilgileri bütüncül bakış açısıyla bir araya getirerek önemli bir çalışmaya 
imza atmışlardır. Son zamanlarda ortaya konan kıymetli çalışmalarla her kesim tarafından daha yakından takip edilen divan şiiri ve bu şiir vadisinde şiirler ortaya koymuş olan sultan ve şehzadelerin eserleri üniversitelerimizin edebiyat konularına meraklı öğrencilerinin ve konu ile yakından ilgili bulunan halkın dikkatine sunulmuştur. Bu eserin konu ile alakalı olarak yapılacak daha derinlikli çalışmalara ışık olacağı kanaatini taşıdığımızı söylemek isteriz.

\section{Kaynakça}

Öztoprak, Nihat vd. (2020). Osmanlı Hanedan Şairleri, Osman Bey'den Sultan Vahdettin'e. İstanbul: İdeal Kültür Yayıncılık.

“COPE-Dergi Editörleri İçin Davranış Kuralları ve En İyi Uygulama ilkeleri” çerçevesinde aşağıdaki beyanlara yer verilmiştir:

Etik Kurul Belgesi: Bu çalışma için etik kurul belgesi gerekmemektedir.

Çıkar Çatışması Beyanı: Bu makalenin araştırması, yazarlığı veya yayınlanmasıyla ilgili olarak yazarın potansiyel bir çıkar çatışması yoktur.

The following statements are made in the framework of "COPE-Code of Conduct and Best Practices Guidelines for Journal Editors":

Ethics Committee Approval: Ethics committee approval is not required for this study.

Declaration of Conflicting Interests: The author has no potential conflict of interest regarding research, authorship or publication of this article. 